\title{
Young People, Precarity and Global Grammars of Enterprise: Some Preliminary Provocations
}

\section{Juventud, precariedad y gramáticas globales del emprendimiento: algunas provocaciones preliminares}

DIEGO CARBAJO (Universidad del País Vasco / Euskal Herriko Unibertsitatea) \& PETER KELLY (RMIT University)

Artículo recibido: 29 de junio de 2018

Solicitud de revisión: 26 de noviembre de 2018

Artículo aceptado: 15 de enero de 2019

Carbajo, Diego and Kelly, Peter (2019). Young People, Precarity and Global Grammars of Enterprise: Some Preliminary Provocations. Recerca. Revista de Pensament i Análisi, $24(1)$, pp. 61-91.

\begin{abstract}
At a time in which labour markets are becoming increasingly globalised and precarisation processes are altering young people's working and living conditions, a whole network of public and private agencies are developing different entrepreneurship programmes as the main mechanism to deal with youth exclusion and unemployment. Grounded in two ongoing research projects conducted in Europe and Australia, this article proposes a preliminary, thought-provoking engagement with the concept of global grammars of enterprise to examine how the truth regimes are framed and articulated in these networks. We argue that this concept enables us to identify, examine and analyse the shifting, unstable, but always strategic power relations between the governmental discourses on entrepreneurship and the enterprising behaviour and dispositions of persons and groups, and the particular «declensions» and local «translations» of the ideas of entrepreneurship that organisations and young people perform within a process of globalised precarisation.
\end{abstract}

Key Words: Youth, precarisation, work, entrepreneurship, digital disruption

Resumen

Al albur de la globalización de los mercados laborales, al mismo tiempo que ciertos procesos de precarización están alterando profundamente las condiciones de vida y de trabajo de las personas jóvenes, se despliega toda una red de agentes públicos y privados que buscan fomentar el emprendimiento como principal mecanismo para enfrentar la exclusión y el paro juvenil. Fundamentado en dos proyectos de investigación en curso en Europa y 
Australia, el artículo se involucra preliminar y provocativamente con el concepto analítico de gramáticas globales del emprendimiento para analizar cómo se enmarcan y articulan los regímenes de verdad de estas redes. Argumentamos que este constructo posibilita abordar las inestables y estratégicas relaciones de poder entre los discursos gubernamentales del emprendimiento y las disposiciones y los comportamientos; las declinaciones particulares y las «traducciones» locales que la juventud y algunas organizaciones afines realizan de ellos en el marco de un proceso de precarización globalizado.

Palabras clave: Juventud, precarización, regímenes de trabajo, emprendimiento.

\section{INTRODUCTION: YOUNG PEOPLE AND GLOBAL GRAMMARS OF ENTERPRISE}

In the context of long-term historical transformations in ever-more globalised labour markets, the emergence of a so-called «digital disruption»/«Third Industrial Revolution» and the still unfolding aftermath of the 2008-o9 Global Financial Crisis (GFC), precarity has become the key characteristic of the contexts in which many young people in the liberal democracies of the OECD/EU seek a «solution» to the challenges and opportunities of making a «transition» to adulthood. At the same time, government agencies and departments, educational institutions, businesses and NGOs are developing and promoting different enterprise/entrepreneurship programmes as the primary mechanism to deal with young people's marginalisation, precariousness and unemployment.

This paper, which is grounded in two on-going research projects related to self and social enterprise in Europe and Australia, introduces the analytical concept of global grammars of enterprise. Our use of grammar does not have its foundations in Derrida's (1976) concept of grammatology. Rather, it is closer to the «looser» use of the term grammar as employed by authors such as Braudel (1987), Virno (2004) or Martuccelli (2007). It is a way of addressing the use of the institutionalised and formalised representations of entrepreneurship. In its broadest and most general sense the concept enables us to identify, examine and analyse a number of things, including the shifting, unstable, yet always strategic power relations between governmental discourses of «enterprise» and the performances and actions of enterprise, and the enterprising behaviour and dispositions of persons and groups, together with the local, «vernacular» «specific translations» of the ideas of 
entrepreneurship carried out by organisations and young people in particular places.

In these preliminary provocations, however, our scope is more limited. In what follows we will consider the ways in which the downstream effects of the GFC, emerging digital disruptions and diverse forms of precarisation shape young people's lives in different contexts around the world. We follow this discussion with an introduction to the ways in which, in Australia and the EU/Spain, various agencies, organisations and institutions understand, articulate and situate these disruptions and experiences through what we are calling a grammar of enterprise. Our choices of these particular contexts are largely pragmatic, while at the same time they are illustrative of many of the points that follow. The first author is currently the holder of a Postdoctoral Fellowship ${ }^{1}$ from the Basque Government and the second author is leading an Australian Research Council Discovery Project. ${ }^{2}$ Both projects are fundamentally concerned with the entanglements of young people, education and training, and work and provide us with a means to identify and trace the emergence of what we are calling global grammars of enterprise. In the Australian context, we engage with the Foundation for Young Australians «enterprise skills» agenda in its New Work Orders initiative. In the context of the EU and Spain, we examine an array of government documents that, at first glance, establish a vertical integration of an «entrepreneurship» policy agenda from «Brussels to Lakua (Basque Country)», but which, on closer inspection, seem to involve processes of «translation» that are often «vernacular», rather than «literal». Our aim here is not to perform a comparative analysis. Rather, our intention is to illustrate, all too briefly given the space available here, a limited number of manifestations of this grammar in order to describe elements of the vocabularies that a global grammar of enterprise permits and normalises. Our preliminary provocations aim to highlight a number of the tensions, contradictions and ambiguities that emerge in the attempts to forge entrepreneurial young people who are best able to practise a paradoxical form of freedom characterised by uncertainty and precarity.

1 The project Grammars of Self-entrepreneurship in the Basque Country from an International Perspective has been funded by the «Doctoral Research Staff Improvement Programme 2017 2020» run by the Basque Governments Department of Education (POS-2016-1-0081).

2 ARC (DP170100547) Arts-based social enterprise and marginalised young people's transitions Peter Kelly, Grace McQuilten, Kim Humphrey, Deb Warr and Amy Spiers 


\section{YOUNG PEOPLE, THE CRISIS AND PRECARITY}

The downstream effects of the GFC have compounded the health and well-being, educational and labour market effects and consequences of 30 or 40 years of increased globalisation, the emergence of a more flexible capitalism and the ways in which the Thatcherism and Reaganism of the 1980 os have morphed into the globalised triumphalism of neo-Liberal capitalism and arts of government (Lorey, 2015). The still echoing repercussions of what some called the Great Recession in Europe and the US, and the emergence of sovereign debt crises and significant austerity programmes in many EU/OECD economies, represent a largely successful framing of responses to the downstream effects of the GFC as being principally about levels of State debt. Over the last decade youths and young adults have been carrying a significant burden in relation to these longer run, and more recent, crises and disruptions. This includes a series of highly consequential transformations in young people's education and employment circumstances and opportunities, even though they take on different forms in different spaces. These consequences affect a range of physical and mental health and well-being issues, including anxiety disorders, use of alcohol and other drugs, access to care and support services formerly provided by the State; consumption, housing, relationship and parenting aspirations related to what we have come to understand as the «norms» of being independent or «autonomous» and of «adulthood»; and a sense of self as a «citizen» in the liberal democracies (Kelly, 2016).

A number of influential work sociologists have claimed that, during these early years of the $21^{\text {st }}$ century, the nature and meaning of work has changed. Work, the regulation of labour markets, work identities, the conception of work, the position of work in our lives, the times and the spaces and places in which work occurs have been, and continue to be, transformed. In many of the OECD economies, labour markets are increasingly characterised by casual and part-time work and the over-representation of particular populations (females and young people) in that kind of employment (Beck, 20oo; Bauman, 2005; Kelly, 2013).

Richard Sennett's (2006) influential analysis of «flexible capitalism» identifies three key, unfolding, processes that are shaping the emergence of increased uncertainty and precariousness. The first of the processes that Sennett (2006: 37-47) identifies is the «shift from managerial to shareholder power» in many organisations. Takeovers, mergers, acquisitions and buyouts 
became the playthings of increasingly mobile capital. This situation was enabled by the frenzied activity of wealth-holders seeking wealth creation, and facilitated by the demands for the interests of mobile, digitised capital to be granted more value than those of more «territorially fixed players» such as nation states and «flesh and blood» workers (Beck, 200o). This globalised flow of predatory capital has ushered in the second process, which Sennett identifies as energising the «flexibilisation» of capitalism. He argues that «empowered investors» in greatly enhanced, globalised circuits of capital demand short-term rather than long-term results (2006:39-40). As the same author also indicates, organisations have had to transform their institutional processes, practices and structures to satisfy the «fetishisation» of the short term by impatient globalised capital (2006: 40-41). ${ }^{3}$ In Sennett's understanding of flexible capitalism, this is a profound change from the «steel hard shell» of Weberian bureaucracy and a continuing driver of the re-engineering, reworking and re-invention of the organisation (and of the self) that accompanies demands for flexibility. The third driver of this postbureaucratic, flexible capitalism is, for Sennett, the information, communication and transportation revolutions of the last four decades, which have transformed the nature of all productive activities. Under the uneven influence of the global development and deployment of these technologies, $21^{\mathrm{st}}$-century work looks different and is imagined and regulated in different ways. These forces are not only felt at the organisational level. They are also highly consequential for the individual self, that constantly encounters these norms of economic activity and must make choices and practise his/her freedom in the spaces structured by these demands (Kelly, 2013).

The effects of these economic, political and cultural changes are the basis for the increased uncertainty that characterises many areas of contemporary life, especially for young people. This generalised uncertainty shows little sign of reversing and represents a new kind of normality in the liberal democracies of the OECD (Neilson \& Rossiter, 2008; Kalleberg, 2009; Lorey, 2015; Castel, 2016; Bobkov \& Kvachev, 2017). Recent debates about these emerging global processes position precarity not only as a limit or a boundary, but also as a condition that allows the emergence of renewed and ambivalent subjectivations that overflow analytic categories such as class (Della Porta et al., 2015; Armano et al., 2017; Alberti et al., 2018). Isabell Lorey's (2015) recent

3 Thomas Piketty's (2014) work -and the work of others engaged in analysing local/global inequalities- is useful read alongside this form of analysis, even though the concerns are different. 
and highly productive work establishes three dimensions for understanding «the precarious». It can be approached at a socio-ontological level (precariousness), as a state or a condition (precarity), and as a process (governmental precarisation). First, based on Butler's thinking (2004, 2009), she departs from the basis of an ontological and constitutive level of precariousness related to life and to bodies that affects all human beings. Second, as it is not «something» that is «natural» but «something» that is «always relational and therefore shared» (Lorey, 2015: 19), precarity refers to the political process of the production and differential distribution of protections and safeguards from precariousness. Third, as precarity is socially and politically determined and distributed, following Foucault's developments (2008, 2009), she establishes a third «processual» dimension of precarity, that is, a governmental type (Lorey, 2015: 23). Understanding precarisation as both rationality of government and technology of self-management opens up a powerful perspective enabling us to grasp how we are governed, and govern ourselves, in and through precarity (Lorey, 2015: 63):

(...) governmental precarisation emphasises how the conduct of state governance and individualised self-governing are intertwined in a mode of governing that uses insecurity as its main tool. Understanding precarisation governmentally [...] makes it possible to problematise the complex interactions between an instrument of governing, economic conditions of exploitation, and modes of subjectivation whilst appreciating the ambivalence between subjugation and freedom (Lorey, 2017: 200).

In this sense, precarisation captures a paradoxical process that emerges, largely, from the world of work, and which is experienced as a form of vulnerability and/or uncertainty. At the same time it can also be «felt» as a form of freedom that gives rise to «new ways» of living and subjectivations. Here, we can imagine how freedom might become ambiguous when both precarisation and the «calls to be entrepreneurial» are encountered and performed differently (Papadopoulos et al., 2008: 232-233) by the «young self».

It is in these ways of articulating particular forms of individual freedom and choices that we argue that a global grammar of enterprise has emerged to «render the reality» of young people, education and training, work, and the nature of the transitions to adulthood and citizenship in the Liberal democracies knowable in ways that promise to make these problems «governable» (Rose \& Miller, 1992). The following sections provide some evidence of these «emergences» in Australia and in the EU/Spain/the Basque Country. 


\section{THE FOUNDATION FOR YOUNG AUSTRALIANS «FYA»: ENTERPRISE SKILLS IN AUSTRALIA}

\subsection{The Challenge}

We need the next generation of young Australians to be more enterprising, innovative and entrepreneurial to drive our nation's future (FYA, 2016: 6).

The Australia-based research from which this sense of global grammars emerges has a number of elements, including a significant period of time publishing work about neo-Liberalism, youth at risk, the entrepreneurial self and the self as enterprise (see, for example: Kelly, 2000, 2006, 2013; Kelly \& Pike, 2017). This thinking has also given shape to, and emerged from, two substantial projects on young people and social enterprise funded by the Australian Research Council. ${ }^{4}$ In this section, however, we focus on a leading youth advocacy organisation and its particular, though «global», and highly influential framing of New Work Orders, namely, young people and what it calls «enterprise skills».

The Foundation for Young Australians (FYA) is an Australian Third Sector Organisation (TSO) that works with, and for, young people to advocate «youth issues». In Australia, the FYA is a prominent voice in the «youth space». Its current CEO (Jan Owen) is often cited in the media and speaks frequently on the core elements of the FYA's mission, vision and initiatives. In many respects, hers is a trusted voice in the mainstream of «youth affairs». The story and profile of the FYA is indicative of the ways in which the advocacy of «youth issues» by similar organisations have figured prominently in public discourse in many of the OECD/EU economies over the last 30 to 40 years.

For much of the last decade, the FYA has commissioned and conducted research on the changing world of work, on the education and training regimes that can meet the «needs» of this changing world of work, and on the attributes and characteristics of the forms of personhood that young people must develop to cope with these changes. More recently, this work has cohered - in a number of reports - around what the FYA calls the New Work

\footnotetext{
ARC (LP100200153) Capacity Building and Social Enterprise: Individual and Organisational Transformation in Transitional Labour Market Programmes. Project team: Peter Kelly, Lyn Harrison, Chris Hickey, Perri Campbell. ARC (DP170100547) Arts based social enterprise and marginalised young people's transitions. Project team: Peter Kelly, Grace McQuilten, Kim Humphrey, Deb Warr and Amy Spiers.
} 
Order. This series is frequently referenced in the media by corporations and governments, other TSOs, influential individuals and the universities we work for. These ideas that frame and emerge from this series are taking on the form of an influential new orthodoxy. ${ }^{5}$ The FYA identifies three broad themes in its telling of the story of labour market change:

Automation: Ever-smarter machines are performing ever-more human tasks-taking, replacing or eliminating the need for whole categories of employment.

Globalisation: Our workforce is going global and the global workforce is coming to us.

Collaboration: Technology is increasing the potential for cooperation and collaboration across multiple platforms (FYA, 2015: 7).

In discussing these themes in greater detail, the FYA (2015: 8) sees both opportunity and risk for young people in these «disruptions». In the first instance, the FYA suggests that the «barriers to entrepreneurship are falling. Technology and globalisation are making it easier and cheaper at multiple stages in the lifecycle of a start-up». In addition: «New technologies and ways of working are providing unprecedented flexibility in how and where people work, which is one of the key drivers of worker happiness». Finally, on the opportunity side of the ledger: «Technology has accelerated the division of labour and enabled companies to divide up work into ever-smaller tasks that can be sourced from a global labour pool». But «risks» also come with opportunities. Digital disruption threatens to make jobs «disappear» on a massive scale - and young people are already over-represented among the unemployed: «Already nearly one in three young people in Australia are either unemployed or underemployed. And over the past 25 years, nearly one in ten unskilled male workers lost their jobs and never found another» Growing income and wealth inequality is a global phenomenon (Piketty, 2014) that digital disruption threatens to exacerbate:

As skilled labour becomes more valuable, and unskilled labour becomes a global commodity, incomes are likely to continue to diverge. Pay for the skilled will rise, while

5 See this link for evidence of this emerging orthodoxy: https://www.google.com.au/search?hl=en\&as_q=\&as_epq=new+work+order+research+se ries\&as_oq=\&as_eq=\&as_nlo=\&as_nhi $=\& \mathrm{lr}=\& \mathrm{cr}=\& a s_{-}$qdr=all\&as_sitesearch=\&as_occt=bod $\mathrm{y} \& \mathrm{safe}=$ images\&as_filetype $=\& a s_{-}$rights $=$ 
unskilled workers will be forced to compete with low cost automation at home and foreign workers abroad (FYA, 2015: 8).

The FYA identifies one final risk in these labour market changes: «a risk of increased employment insecurity. More than half of new jobs in advanced economies since the 1990 o have been temporary, part-time or self-employed». Unemployment. Inequality. Insecurity. In imagining these as risks and, at the same time, glossing over them, the FYA seems to suggest that these are inevitable aspects of life in $21^{\text {st }}$-century capitalism. Indeed, the FYA's research and advocacy response is framed by a sense that, given the trajectory of the changes it identifies, governments, education systems, businesses and community agencies need to develop approaches to young people's education and training that fosters and enables them to develop what it and others see as «enterprise skills».

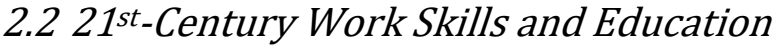

Here, the FYA's positions are, as our concept of global grammars of enterprise suggests, emblematic of much of the high-level political rhetoric and policy discourse across the governments of member states of the OECD and $\mathrm{EU}$, and their agencies, as the future contours of globalised labour markets become more apparent. To be able to see themselves becoming actively engaged in work sometime in the future, young people need to be provided with forms of education and training that equip them with «enterprise skills». For the FYA (2017: 5), enterprise skills are «transferable skills that enable young people to engage with a complex world and navigate the challenges they will inherit». These skills, it is claimed, «are not just for entrepreneurs; they are skills that are required in many jobs. They have been found to be a powerful predictor of long-term job success». What are often called generic, soft or $21^{\text {st }}$-century skills include: «Problem-solving; Communication skills; digital literacy; presentation skills; critical thinking; creativity; financial literacy».

The New Basics report (FYA, 2017), in the Future of Work series, emerged from an array of data-mining activities that include examining hundreds of thousands of job advertisements for «keywords» in order to identify the skills that employers were looking for. In assessing whether young people possessed the sorts of enterprise skills and personal character attributes that might inoculate them against globalising structural labour market transformations, 
the report references a range of data sources including the Programme for International Student Assessment (PISA, the international student testing programme conducted by the OECD). The report presents a snapshot of a number of indicators from PISA data that suggests that young Australians are not doing so well in developing these «enterprise skills». In relation to problem-solving, the FYA (2017:17) argues that «approximately 1 in 3 Australian 15-year-olds (35\%) demonstrated low proficiency in problemsolving [...] with $50 \%$ of low socio-economic students and $62 \%$ of Indigenous students recording low proficiency». Digital literacy indicators raised similar concerns for the FYA (2017: 17), since approximately «1 in 4 Australian 15year-olds $(27 \%)$ demonstrated low proficiency in digital literacy». The same was true of the results for financial literacy: «approximately 3 in 10 Australian 15-year-olds (29\%) demonstrated low proficiency in financial literacy» (FYA, 2017: 17).

If, as these metrics suggest, large numbers of young people lack the enterprise skills required in the new worlds of work, how are they to be developed? The FYA recommends that Australian governments lead a dramatic rethinking and reimagining of many dimensions of education systems:

Having clearly understood that employer demand for these skills is increasing, we need to better support their development in our education and training systems. The skills most commonly demanded by employers, like communication, teamwork, problemsolving, creativity, and digital literacy, can be built into our training systems in a number of ways, including by:

Setting the scene with curriculum;

Rethinking teaching methods;

Developing teachers;

Partnering with employers; and

Providing a clear picture with live labour market data (FYA, 2017: 19).

The aspiration here is for young people to be able to embody the enterprise and entrepreneurialism that many organisations and governments have come to see as structuring the purposes of education at the start of the 
$21^{\text {st }}$ century. This is particularly true in contexts of disruption and rupture that have resulted in significantly high, and enduring, levels of youth unemployment, precarity and marginalisation.

The education system is the space that will have the greatest responsibility for developing these skills. In a Foreword to The New Work Order, the FYA's CEO Jan Owen indicates that in relation to these enterprise, generic, soft or $21^{\text {st }}$-century skills:

An enterprising skills education would:

- begin early in primary school and build consistently, year on year, throughout high school

- be provided in ways that young people want to learn: through experience, immersion and with peers

- provide accurate information and exposure about where future jobs will exist and the skills to craft and navigate multiple careers

- engage students, schools, industry and parents in co-designing opportunities in and outside the classroom (Owen, 2015: 2).

The FYA provides a number of examples of where this approach to education and training already exists. And these examples tend to take the character of the world, and of future worlds of work, as given; that is, they see the nature of capitalist exchange relations as a common-sense model of what is to be done and how to do it. Frankston High School, a state-funded public secondary school in the south-east suburbs of Melbourne runs a course $(4$ hours/week) for year 9 and 10 students (young people, approximately 16 years old) that is entitled Innovating in the $21^{\text {st }}$ Century, and which is framed by the following propositions and assumptions:

Opportunities for current students and future school leavers are changing. Many of the students leaving schools do not have the skillset to fulfil positions in the future workplace or are aware of the changing opportunities for them [...] A huge focus of the subject is looking at the future of work and what are the skills required to be productive and happy in their future workplaces. We will look at team building, collaboration, productivity techniques and mindfulness (FYA, 2017: 21). 


\section{FROM «BRUSSELS TO LAKUA»: EUROPEAN GRAMMARS OF ENTREPRENEURSHIP}

The Basque Country, Spanish and European Union (EU) level analysis we present here is grounded in a Postdoctoral fellowship project, and in on-going collaborations with a number of networks. ${ }^{6}$ These programmes are concerned with exploring grammars of enterpreneurship in the Basque Country, and the ways in which various organisations and individuals reproduce and translate understandings of young people, education, training, precarious work and enterprise. This section describes some of the key moments and movements in the recent EU, Spanish and Basque framing of the «crisis», young people's employment and precarisation, and the promise that reinvigorating «entrepreneurialism» will provide some solutions to these issues.

There are, for example, significant similarities between the reports produced by the FYA and some drawn up by the Basque Economic and Social Council (CES/EGAB).7 The CES/EGAB's latest report, The employability and access to the labour market of the youth of the Basque Country from a comparative European regional perspective (CES/EGAB, 2018), stresses the need for young Basque people to acquire the skills and flexibility that an Information and Communication Technologies (ICT) based labour market will require. This report, supported by documents such as Skills for a Digital World (OECD 2016) or Future skill needs in Europe: critical labour force trends (CEDEFOP, European Centre for the Development of Educational Training, 2016), predicts that changes in the content of jobs and work organisation through increased automation and robotisation will affect the distribution of occupational and qualification structures. As a result, expected employment growth across the EU will be digitalised and concentrated in service sectors and high-skill occupations that will, alongside conventional digital, scientific and technological skills, demand «soft skills» (such as social and emotional

6 As said, the project Grammars of Self-entrepreneurship in the Basque Country from an International Perspective has been funded by the «Doctoral Research Staff Improvement Programme 2017-2020» run by the Basque Government's Department of Education (POS2016-1-0081). Collaborations include the «Stable Research Group (Type A) of the Basque University System», called Social change, precarity and identity in contemporary society (IT706-13) and the Network of Youth and Society Studies funded by the «State Plan for Scientific and Technical Research and Innovation 2013-2016» [CSO2015-71988-REDT].

7 The Basque Economic and Social Council (CES/EGAB) is a consultative body of the Basque Government and the Basque Parliament. It comprises representatives of unions, business associations, chambers of commerce, consumer associations and experts. It was created to enable participation of the different economic and social stakeholders in the economic and social policy of the Basque Country. 
intelligence, and expressiveness), and other cognitive skills (complex problemsolving, collaborative skills, creativity, leadership). In addition, the report positions «lifelong learning» as a prerequisite «that allows the active population to develop their skills and abilities in parallel to the changes and requirements that occur in the production system» (CES/EGAB, 2018: 105).

\subsection{From Brussels...}

EU policies targeting the skills and mindsets of young people which have been developed after the GFC represent some of the key emergency measures taken to counter young people's high unemployment rates and precarity (employment, social, housing, well-being) (European Commission, 2010). Since the 1997 Amsterdam Treaty, this complex network of policies has been developed in different stages. As Ginesta (2013: 60) shows, the 2000 Lisbon European Council proposed active incentive mechanisms to position entrepreneurship as the driver of European economic long-term growth. In 2003, the Green Paper on Entrepreneurship in Europe highlighted the need to develop comprehensive programmes to promote entrepreneurship on an individual, business and nation state level. The measures taken after those initiatives were reflected in the Small Business Act passed in 2008 and reviewed in 2011. The two acts serve as the foundations of the current Entrepreneurship 2020 Action Plan: Reigniting the entrepreneurial spirit in Europe, which seeks «a far-reaching cultural change to make entrepreneurship the engine of economic growth in Europe» (European Commission, 2012: 4). This «promise» will be achieved through three main objectives: 1 ) developing entrepreneurial education and training; 2) creating the right business environment; and 3) identifying and promoting role models and reaching out to specific groups (the unemployed, young people, women, seniors, immigrants, etc.). The way in which the introductory paragraph defines the GFC provides further evidence of a governmental investment in this particular understanding of entrepreneurship:

Before the on-going economic and financial crisis, the European economy faced structural challenges to its competitiveness and growth, and obstacles to entrepreneurship. Many of these persist, but the crisis has also been a catalyst for deep change and restructuring (European Commission, 2012: 3). 
Following the GFC - as a catalyst and an accelerator- the call for persons to become entrepreneurial in order to improve their «employability» has become a «motif» running through all the different employment policies (Keune \& Serrano, 2014; Muñoz \& Santos, 2017). Significantly, young people are one of the main target populations of these governmental processes (Serrano \& Martín, 2017):

Whether or not they go on to found businesses or social enterprises, young people who benefit from entrepreneurial learning develop business knowledge and essential skills and attitudes including creativity, initiative, tenacity, teamwork, understanding of risk and a sense of responsibility. This is the entrepreneurial mind-set that helps entrepreneurs transform ideas into action and also significantly increases employability (European Commission, 2012: 6).

Here, entrepreneurship is an attitude, a skill, a moral disposition towards contexts of uncertainty that seeks to engage individuals and enterprises by articulating «creativity, innovation, risk taking, ability to plan and manage projects in order to achieve objectives» (European Commission, 2017).

\section{2 ...to Lakua}

Among the southern Europe states, Spain suffered one of the highest rates of youth unemployment following the GFC. According to Eurostat (2017), the rate of youth unemployment (in the 15 to 29 age range) in Spain reached a peak of $41.4 \%$ in 2013 . In 2017 , the youth unemployment rate of $28.7 \%$ was, along with other Mediterranean countries, still one of the highest in Europe, over twice that of the EU-28 average. In the case of the Basque Country, these rates were lower and more similar to northern European states. According to the Basque Youth Observatory (OVJ, 2018), while the peak of youth unemployment was reached in 2014 with a rate of $29.5 \%$, by 2017 it had dropped to $15.1 \%$. Even though current unemployment rates in Spain are lower, levels of part-time jobs and temporary employment are still troubling (Benedicto et al., 2017: 129). In Spain, the rate of temporary employment in 2017 stood at $57.9 \%$ (Eurostat, 2017), and over 60\% in the Basque country (OVJ, 2018), among the highest in Europe.

Faced with this situation, and following a radical deregulatory labour market reform in 2012, the promotion of entrepreneurship among young people was presented as a prioritised political strategy designed to improve the employability of this population (Boletín Oficial del Estado, 2013). The 
scope for the government to promote entrepreneurship is reflected in the Entrepreneurship and Youth Employment Strategy 2013/2016 (currently extended to the 2017-2020 period without any apparent modifications) and in the National Youth Guarantee Implementation Plan (Ministerio de Trabajo y Seguridad Social, 2014), financed by the European Social Fund. These strategies consist mainly of economic measures (rebates and bonuses, financing and unemployment subsidies and capital payments), as well as other noneconomic steps relating to entrepreneurship training in which a variety of public and private intermediary agents take part.

While the Spanish government acts as a coordinator and proponent of the EU's employment policies, in the Basque autonomous region entrepreneurship strategies closely align with the EU directives without any apparent mediation of the national government (Gobierno Vasco, 2017). The Basque Country Government's general plan, based on its own Law for the Support of Entrepreneurs and Small Businesses (Parlamento Vasco, 2012), has been recently updated until 2020 with a budget of 295 million euros (Gobierno Vasco, 2017). This ambitious strategy involves all the local administrative institutions and a wide range of public and private agencies, and it mirrors economic and social measures outlined at the national financing level. For example, in the Basque School Curricula - in all educational institutions there is a strong emphasis on fostering positive attitudes towards entrepreneurship and its values (Gobierno Vasco, 2014). The entrepreneurial skills, mindsets and attitudes that are suggested in the CES/EGAB (2018) are already being taught extensively in Basque universities and vocational training centres, as well as in primary, secondary and high schools. In this sense, Lakua (as the Basque Government is referred to by locals) is competing, «globally», to «cultivate» these behaviours and dispositions in local populations. The government presents this strategy as a tool for boosting economic growth by «generating and reinforcing an entrepreneurial culture» and by producing a «privileged entrepreneurial ecosystem» (Gobierno Vasco, 2017: 68).

This multi-scalar network of policies that we have all too briefly sketched for the cases of Australia, the EU, Spain and the Basque Country is only one (albeit important) part of the «apparatus» (Foucault, 1980: 194-195) or «assemblage» (Latour, 2005: 208) that we want to make thinkable through the notion of global grammars of enterprise. Drawing on our descriptions of the ways in which organisations such as the FYA and the agencies and departments of the EU and the Basque Country Government imagine and enact the entanglement of young people, education and training, work and 
enterprise, in the section that follows we will identify and analyse significant elements of the vocabularies that emerge from and structure these grammars of enterprise.

\section{GLOBAL GRAMMARS AND VOCABULARIES OF ENTERPRISE}

As we suggested earlier, our use of the term grammar is a way of addressing the preferred, normative rules of use of the institutional and orthodox representations of entrepreneurship and which condense semiotic and material components of social processes that emerge from, and shape, a globalised order of work, life and relations in contemporary societies (Kelly, 2013). By gathering together discursive and semiotic-immaterial elements such as political, ideological or moral imperatives/interpellations that are often «place-based», it also points to a «geography of entrepreneurship» (Kelly \& Pike, 2017). The concept gestures to the materiality of agencies, apparatuses and institutions that converge in the implementation and development of the policies of entrepreneurship (Foucault, 1980: 194-195). Even though our current focus is on the governmental character (Foucault, 2009) of this process of «entrepreneuralisation» of contemporary experience (Deleuze, 1992: 6), this conceptualisation aims to detect, in further work, how a code of conduct, or a morality, is appropriated and embodied in «devious ways», generating «failures», «anomalies» and «unforeseen effects» (Merton, 1936). Understanding grammar in this way allows us to introduce into our analysis those other «enunciations» (as configurations of the subject), uses and meanings that do not fit in with, or which escape from, the prescribed rules of those governmental programmes that seek to promote young people's entrepreneurialism. In the next paragraphs we briefly identify and describe the following elements of the vocabularies of enterprise: The Self as Project; Self-Fulfilment; Creativity; Flexibility; Viability; Risk Taking.

What is important in what follows is a sense that these grammars of enterprise have, over the last three decades, been energised, given a productive form that can enact realities by various players, including business schools, management consultants/experts/gurus and «globalising» organisations. These actants have played significant roles in what Nigel Thrift (2005) has termed the «cultural circuits of capitalism» (see also Boltanski \& Chiapello, 2005; Fernández Rodríguez \& Medina-Vicent, 2017). These «cultural circuits» have been able to process, package and place management knowledge in all kinds of 
fields by providing mobile formulas and models that can be applied in (transferred to) many diverse situations. These packages of knowledge, technologies, methods and their equations can be easily detected not only in private corporations, but also in state and public institutions, TSOs, Not-forProfits, NGOs and social enterprises.

The Global Entrepreneurship Monitor (GEM), for example, prepares a global census of entrepreneurship, and produces and circulates performatively - a range of indicators of entrepreneurship. Based on a large network of «branches» in local universities and research institutes, it provides regional analyses, international comparisons and different state rankings of entrepreneurship. These scientific policies have collaborated in «joining» entrepreneurship and/to young people to create a powerful «artefact of expertise» (Kelly, 2000). This refers to an artefact that has been «turbocharged», so to speak, by the ways in which young people in many of the OECD/EU democracies have been, and continue to be, «over-burdened» by the confluences of the GFC, the rapidly emerging, though unevenly distributed and experienced, possibilities of the so-called «digital disruption» that threatens to make hundreds of millions of jobs «disappear», and by precarisation.

\subsection{The Self as Project}

Since the 1970 , the notion of «project» has been consolidated as a specific way of thinking and producing contemporary subjectivities as a reflexive enterprise (Beck, 1992; Rose, 1999; Kelly, 2006, 2013; Bröckling, 2016). As such, a «project» is a way of organising reality through certain objectives, closed time periods, checkpoints and feedbacks. It is a process of rationalisation, a technology through which we relate to ourselves and to others (Bröckling, 2016: 172). We are all encouraged, even compelled, to have a life-project composed of several on-going projects. Being without any kind of project is understood as a form of deficit, a personal failure. Within this framework, the entrepreneurial project is a technique of self-management, and «project management» a sort of lifestyle (Kelly, 2013: 137) that has become the normative way of conducting oneself in a disciplined manner. 


\subsection{Self-Fulfilment}

The idea of «self-fulfilment» is linked to the dominant psychological representation of the individual in western societies (Rose, 1999). By articulating such things as desires, personal will and freedom, it plays a crucial role in the legitimation and translation of grammars of enterprise. The ubiquitous slogan, «If you can dream it, you can be it», condenses the promises made to young people by this grammar through educational institutions and vocational training markets (Morgan \& Nelligan, 2018: 149). Similarly, while «vocation» is presented as something feasible to everyone, «passion» is invoked as an individual inner capacity that has to be performed and self-cultivated by the young person who aspires to achieve some kind of career success (Kelly \& Harrison, 2009).

If we consider that the democratisation of the search for self-fulfilment through work is relatively new (Boltanski \& Chiapello, 2005), and its expansion has much to do with a romanticised representation of the artist, its actual function as a normalising imperative becomes clearer:

Perhaps those who work creatively, these precarious cultural producers by design, are subjects that can be exploited so easily because they seem to bear their living and working conditions eternally due to the belief in their own freedom and autonomy, due to self-realisation fantasies. In a neoliberal context they are exploitable to such an extreme that the State even presents them as role models (Lorey, 2006: 6).

In a context where working conditions are increasingly precarious, the promises of self-fulfilment and self-determination that are central to the grammar of enterprise become the means by which «conduct is conducted» (Foucault, 2009: 193). In the process, this produces an individual's «unique value proposition», or the call to «be different» (Bröckling, 2016: 196).

\subsection{Creativity}

While little consideration was given to workers' creativity in Fordist capitalism, the notion of creativity as a "productive energy» has become one of the most important and elusive elements of new working regimes (Morgan \& Nelligan, 2018: 15). This change follows a semantic displacement from an anthropological-romantic understanding of creativity as an «instituent» force that generates something new or disruptive (not necessarily productive or good in economic and moral terms) to a rationalised set of techniques that 
seek to produce, standardise and make it profitable (Morgan \& Nelligan, 2018: 3). Thus, creativity is reframed as the ability to imagine, identify or even produce a gap in the «normal order of things» so as to make a profit. The psychological understandings of creativity, and the knowledge produced about it, have made it measurable and translatable to managerial techniques (Bröckling, 2016: 111) under labels such as «innovation» or «intrapreneurship». The contemporary imperative of being creative intersects with the need to act in an entrepreneurial way, pointing towards a renewed economisation and marketisation of the ability of human and non-human actors/materials to generate unforeseen combinations and relations.

\subsection{Flexibility}

In a positive sense, «flexibility» is understood as a cognitive skill that enables the person to adapt and adjust to the different conditions of a new context. It is framed as the optimal personal attitude that enables the person to «best» navigate unpredictable and uncertain environments. As we suggested earlier, this call to be flexible has been identified by Sennett (2006: 115) as the individualisation and subjectivation of the changes in the organisation of corporations towards more adaptable structures in response to the fluctuations of the markets. Management knowledge has paved the way for establishing and stabilising the «truths» of flexibility for young entrepreneurs (Boltanski \& Chiapello, 2005: 461) so that flexibility now operates as a moral category that gestures away from the volatile, inconsistent or fickle person. These ideas of «flexibility» articulate to powerful, omnipresent psychological understandings of resilience that go hand in hand with the category of self-responsibility (Rose \& Lentzos, 2017: 34). Given the consensus on the impossibility of changing the uncertain, precarious nature of contemporary labour markets, it seems that there is little choice but to «go with the flow» by (unceasingly) cultivating flexibility and resilience in order to overcome the next, more than likely, crisis. Flexibility and resilience impel us to remain competitive.

\subsection{Viability}

Closer to the understandings of the market as the ultimate reality, the «viability» of the entrepreneurial project emerges as a compulsory checkpoint for its development and financialisation. The «business plan» of any kind of 
project is an «inscription device» (Latour, 2005) that, subject to economic evaluation by both humans and algorithms, will circulate in the cultural circuits of capitalism, especially in its financial-funding section. The business plan is a stabilisation of an expectation of the productivity that prescribes a programme through which the economic profitability of the project is recreated. It measures the profit «predictability» of the project in an uncertain context (Thrift, 2005: 40). As a crucial technology developed by management knowledge centres, it is unimaginable to conceive of any entrepreneurship project without its itemised, prioritised and justified business plan (Bologna, 2006: 101).

\subsection{Risk-Taking}

Risk-taking is the notion that links and reframes most of the concepts sketched up to this point. Peter Sloterdijk (2013: 71) explains the development of capitalist globalisation through colonialism, mercantilism and the birth of the modern state. At the same time, he also traces the primary forms of entrepreneurs back to the explorers and discoverers of the $16^{\text {th }}$ and $17^{\text {th }}$ centuries. With the discovery and conquest of America, a growing desire for mobility and personal enrichment was triggered throughout Europe. Taking risk on the horizon of uncertainty would be the «new» subjective disposition and the foundation of the modern culture of expanding and reaching out. «Discovery» (fuelled by self-fulfilment and triggered by creativity, organised by the project, and judged feasible through the business plan) becomes a special case of an investing phenomenon, which situates the debtor and the financial sector at the front of the stage. Here, risk-taking refers to the productive moment of both precarisation and grammars of enterprise. That moment, that space, where all sorts of investments that the young entrepreneur makes in/of herself in a context of uncertainty, pushes her to «go beyond herself» in order to cope with that situation of uncertainty - or to meet debt obligations. Ironically, beyond the indebtedness that education and training implies, the case of the entrepreneur who gets a mortgage to fund her project produces a self-referential loop where she is paying, again, for having a job or developing a fulfilling career. 


\section{PROVOCATIONS AND CONCLUSIONS}

We would like to suggest that Grammars of enterprise should not be understood solely as a vertical «grammatical structure» external to individuals. It is more productive to imagine such grammars and vocabularies as normative, as generalised rules of a code that are subject to changes of meaning and direction as the different actants involved in them translate them, make use of them and embody them. As we take this work forward, we want to include in the analysis the capacity for action of non-humans and humans within these «structures», «norms» and codes. They are not forms of subversion, resistance or opposition (such a move would once again romanticise youth as the revolutionary, or creative, historical subject of social change) but as the co-producers of renewed, contingent and ambivalent practices and meanings (Coffey \& Farrugia, 2014; Howie \& Campbell, 2016). So, as we have suggested elsewhere (Kelly \& Pike, 2017), whether young people have the capacity, the desire or the skills necessary to know or to recognise themselves as enterprising cannot be determined in advance. Despite the ambitions of neo-Liberal governmentalities, enterprise cannot be willed into existence. The regulation of the conduct of oneself and others is always an incomplete project. The responsibilities for managing the consequences of this enterprise, and the capacities to identify and manage the risks and opportunities that confront this enterprise are, in neo-Liberal mentalities of rule, imagined as residing in and with the individual. As individuals we are all, young and old, imagined as being responsible for the choices we make, for the outcomes of the choices made (and not made) for managing the material ambiguities and emotional costs of globalised, precarious labour markets (Elliott \& Lemert, 2006).

In the Australian context the FYA, as an influential and «entrepreneurial» youth advocacy organisation, embodies the entrepreneurialism that it imagines will actively prepare young people for the opportunities provided by New Work Orders, and inoculate young people against the risks of these Orders. It plays a significant role in the cultural circuits of neo-Liberal capitalism in Australia that produce and reproduce, translate and articulate, grammars of enterprise. And it does so in ways that are «orthodox», and which create new «orthodoxies» regarding the opportunities and risks of globalised precarious labour markets for young Australians.

Even though the notion of entrepreneurship has a trajectory of at least twenty years in the architecture of the employment policies of the EU 
(Bröckling, 2016: 11), it was not until the GFC, and the implementation of austerity measures, that an entrepreneurial ethos was prioritised as a solution to the precariousness and high unemployment rates among Spanish and Basque young people. The EU directives are based on a strong marketoriented rationale where the growth of entrepreneurship has become powerfully articulated to a «job-rich recovery and prosperity» (European Commission, 2012: 4). This articulation is framed by a problematic assumption that enterprise is a personal quality, and that individuals can embody the qualities of an enterprise (Armstrong, 2005: 6). Indeed, policies aimed at young people at different Spanish governmental levels have been criticised for the individualisation and responsibilisation they are fostering among young people (Carbajo \& Santamaría, 2015; Serrano \& Martín, 2017: 814); for exacerbating the precarisation processes they allegedly seek to address (Santos, 2014; Santamaría, 2018: 17); and for their doubtful impact and lack of coordination (Rodríguez \& Ramos, 2016; Suárez, 2017). Paradoxically, the general call to act entrepreneurially, as a means to navigate uncertainty, compels young people to collaborate in their own precarisation by investing in or mortgaging their futures (Carbajo, 2014). At the same time, uncertainty and precarisation should not be understood as mere blocking tensions, but instead as powerful productive forces (Thrift, 2005) that lead to ambivalent forms of subjectification that oscillate between freedom and subjugation (Lorey, 2017: 204).

In this sense, and as this special issue seeks to do, we have traced some of the elements of global grammars of enterprise, and the ways that they energise processes of individualisation and responsibilisation in the context of precarisation. None of the agencies, organisations, institutions or individuals that we have identified as being important in shaping and articulating these grammars of enterprise are reticent, even shy, about the claims they make about New Work Orders. The same is true regarding the opportunities and challenges that young people face, or the promise that being and becoming entrepreneurial offers young people who are living precarious lives. Indeed, many are evangelical in their invocations, since they appear self-righteous about the self-evidence of their diagnoses and prognoses. Entrepreneurial about enterprise. The challenge as we see it, both here and in future research, is to examine how these grammars function to produce these truths about contemporary and future labour markets; what it is that young people must become; the forms of freedom that they must practise in order to «survive and thrive» under these conditions; and the consequences, intended or otherwise, 
of creating these moral obligations for young people to be and become entrepreneurial.

\section{BIBLIOGRAPHY}

Alberti, Gabriela, Bessa, Ioulia, Hardy, Kate, Trappmann Vera \& Umney. Charles (2018). In, Against and Beyond Precarity: Work in Insecure Times. Work, Employment and Society, 32(3), 447-457.

Armstrong, Peter (2005). Critique of entrepreneurship: people and policy. New York: Palgrave Macmillan.

Armano Emiliana, Bove, Ariana, \& Murgia, Annalisa (Eds.) (2017).

Mapping Precariousness, Labour Insecurity and Uncertain Livelihoods:

Subjectivities and Resistance. Abingdon: Routledge.

Bauman, Zygmunt (2005). Work, Consumerism and the New Poor.

Berkshire: Open University Press.

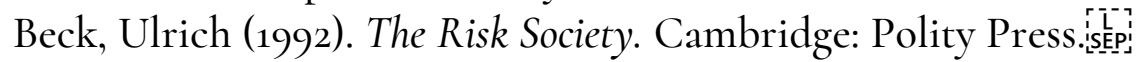

Beck, Ulrich (200o). The Brave New World of Work. Cambridge: Polity.

Benedicto Jorge (Dir.), Echaves, Antonio, Jurado, Teresa, Ramos María, \& Tejerina, Benjamín (2017). Informe Juventud en España 2016. Madrid: Instituto de la Juventud de España.

Bobkov, Vyacheslav \& Kvachev, Vadim (2017). Precarity: Local Disorders or New Global Order? Russian Sociological Review, 16(4), $72-86$.

Boletín Oficial del Estado. (2013). LEY 11/2013, de 26 de julio, de medidas de apoyo al emprendedor y de estímulo del crecimiento y de la creación de empleo. Madrid: Gobierno de España. Retrieved from: http://www.boe.es/boe/dias/2013/o7/27/pdfs/BOE-A-20138187.pdf [Consulted 19 June, 2018]

Bologna, Sergio (2006). Crisis de la clase media y posfordismo. Madrid: Akal. 
Boltanski, Luc \& Chiapello, Ève (2005). The new spirit of capitalism. London: Verso.

Braudel, Fernand (1987). Grammaire des civilisations. Paris: Arthaud.

Bröckling, Ulrich (2016). The Entrepreneurial Self. Fabricating a New Type of Subject. London: SAGE.

Butler, Judith (2004). Precarious Life: The Powers of Mourning and Violence. London \& New York: Verso.

Butler, Judith (2009). Frames of war: when is life grievable? London: Verso.

Carbajo, Diego (2014). Vivir en la precariedad. Trayectorias y estrategias residenciales de los jóvenes en la Comunidad Autónoma del País Vasco. Doctoral Thesis. Universidad del País Vasco-Euskal Herriko Unibertsitatea: Bilbao.

Carbajo, Diego \& Santamaría, Elsa (2015). Trabajo, jóvenes e identidad en un contexto de crisis de los referentes modernos: una aproximación a la figura del emprendedor. Papeles del CEIC, 2015 (3), 1-14.

Castel, Robert (2016). The Rise of Uncertainties. Critical Horizons, $17(2), 160-167$.

CEDEFOP, European Centre for the Development of Educational Training, (2016). Future skill needs in Europe: critical labour force trends. CEDEFOP Research Paper. No 59, Luxembourg: Publications Office. Retrieved from: http://www.cedefop.europa.eu/files/5559_en.pdf [Consulted 19 June, 2018]

CES/EGAB, Consejo Económico y Social Vasco (2018). La empleabilidad de la juventud de la CAPV y el acceso al mercado laboral desde una perspectiva regional europea comparada. Bilbao: Consejo Económico y Social Vasco. Retrieved from http://www.cesegab.com/es-es/Publicaciones/Estudios-e-Informes [Consulted 19 June, 2018] 
Coffey, Julia \& Farrugia, David (2014). Unpacking the black box: the problem of agency in the sociology of youth. Journal of Youth Studies, $17(4), 461-474$.

Deleuze, Gilles (1992). Postscript on the Societies of Control. October, 59 (Winter), 3-7.

Della Porta, Donatella, Hänninen, Sakari \& Siisiäinen, Martti (Eds) (2015). The new social division: making and unmaking precariousness. New York: Palgrave Macmillan.

Derrida, Jacques (1976). Of Grammatology. Baltimore \& London: Johns Hopkins University Press.

Elliott, Anthony \& Lemert, Charles (2006). The New Individualism: The Emotional Costs of Globalization. Abingdon: Routledge.

European Commission (2010). An Agenda for new skills and jobs: A European contribution towards full employment. Strasbourg: European Union. Retrieved from: http://eurlex.europa.eu/resource.html?uri=cellar:776 df18f-542f-48b8-962788aac6dzedeo.0003.03/DOC_1\&format=PDF [Consulted 20 May, 2018]

European Commission (2012). Entrepreneurship 2020 action plan. Reigniting the entrepreneurial spirit in Europe. Brussels: European Union. Retrieved from:_https:/eurlex.europa.eu/LexUriServ/LexUriServ.do?uri=COM:2012:0795:FIN: en:PDF [Consulted 2o May, 2018]

European Commission (2017). Promoting Entrepreneurship. Retrieved from:_https://ec.europa.eu/growth/smes/promotingentrepreneurship_en [Consulted 2o May, 2018]

Eurostat (2017). Youth unemployment rate by sex, age and country of birth. Retrieved from: http://appsso.eurostat.ec.europa.eu/nui/show.do?dataset=yth_emp 1_10o\&lang=en [Consulted 3 March, 2018]

Fernández Rodríguez, Carlos Jesús \& Medina-Vicent, María (2017). Los nuevos discursos del management: difusión, impactos $\mathrm{y}$ 
resistencias. Recerca, Revista De Pensament i Análisi, 20 (4), 7-14. http://dx.doi.org/10.6035/Recerca.2017.20.1

Foucault, Michel (2008). The Birth of Biopolitics. Lectures at the Collége de France, 1978-79. New-York: Palgrave-Macmillan.

Foucault, Michel (2009). Security, Territory, Population. Lectures at the Collége de France, 1977-78. London: Palgrave-MacMilllan.

Foucault, Michel (1980). Power/Knowledge. Selected Interviews and Other Writings 1972-1977. New York: Pantheon Books.

Foundation for Young Australians (2015). The New Work Order: Ensuring young Australians have skills and experience for the jobs of the future, not the past. Melbourne: FYA. Retrieved from: https://www.fya.org.au/wp-content/uploads/2015/o8/fya-futureof-work-report-final-lr.pdf [Consulted 21 May, 2018]

Foundation for Young Australians (2016). 2016-2021 Strategic Plan.

Melbourne: FYA. Retrieved from: http://www.fya.org.au/wpcontent/uploads/2016/o8/FYA-Strategic-Plan-2016-2021.pdf

[Consulted 2o May, 2018]

Foundation for Young Australians (2017). THE NEW BASICS: Big data reveals the skills young people need for the New Work Order. Melbourne: FYA. Retrieved from: http://www.fya.org.au/wpcontent/uploads/2016/o4/The-New-Basics_Web_Final.pdf

[Consulted 20 May, 2018]

Ginesta, Víctor (2013). Apología del emprendedor: Análisis crítico del discurso sobre el interés propio. Oxímora. Revista Internacional de Ética y Política, 3, 56-74.

Gobierno Vasco (2014). Heziberri 2020. Marco del modelo educativo pedagógico. Vitoria-Gasteiz: Gobierno Vasco. Retrieved from: http://www.euskadi.eus/contenidos/informacion/heziberri_2020/e s_heziberr/adjuntos/Heziberri_2020_c.pdf [Consulted 19 June, 2018]

Gobierno Vasco (2017). Plan interinstitucional de Emprendimiento de Euskadi 2020. Vitoria-Gasteiz: Gobierno Vasco. Retrieved from: http://www.euskadi.eus/contenidos/plan_departamental/11_pland 
ep_xileg/es_def/adjuntos/PIE\%202020.pdf [Consulted 19 June, 2018]

Howie, Luke \& Campbell, Perri (2016). Guerrilla selfhood: imagining young people's entrepreneurial futures. Journal of Youth Studies, 19(7), 906-920. doi: 10.1080/13676261.2015.1123236

Kalleberg, Arne (2009). Precarious Work, Insecure Workers: Employment Relations in Transition. American Sociological Review, 74, 1-22. doi:10.1177/000312240907400101

Kelly, Peter (200o). Youth as an Artefact of Expertise: Problematizing the Practice of Youth Studies in an Age of Uncertainty. Journal of Youth Studies, 3(3), 301-315. doi:10.1080/713684381

Kelly, Peter (2006). The Entrepreneurial Self and 'Youth at-risk': Exploring the Horizons of Identity in the Twenty-first Century. Journal of Youth Studies, 9(1), 17-32. doi:10.1080/13676260500523606

Kelly, Peter \& Harrison, Lyn (2009). Working in Jamie's Kitchen: Salvation, Passionand Young Workers. London: Palgrave.

Kelly, Peter (2013). The Self as Enterprise: Foucault and the Spirit of 21st Century Capitalism. Surrey: Ashgate/Grower.

Kelly, Peter (2017). Growing up after the GFC: responsibilisation and mortgaged futures. Discourse: Studies in the Cultural Politics of Education, 38(1), 57-69. doi:10.1080/01596306.2015.1104852

Kelly, Peter \& Pike, Joe (eds.) (2017). Neo-Liberalism and Austerity. The Moral Economies of Young People's Health and Well-being. London: Palgrave-Macmillan.

Keune, Maarten \& Serrano, Amparo (2014). Deconstructing Flexicurity and Developing Alternative Approaches. London: Routledge.

Latour, Bruno (2005). Reassembling the Social. An introduction to ActorNetwork-Theory. Oxford: Oxford University Press.

Lorey, Isabell (2006). Governmentality and Self-Precarization. Transversal. EIPCP, November. Machines and Subjectivation, 1-12. Retrieved from: http://eipcp.net/transversal/1106/lorey/en [Consulted 10 June, 2018] 
Lorey, Isabell (2015). State of Insecurity : Government of the precarious. London: Verso.

Lorey, Isabell (2017). Labour, (in-)dependence, care. Conceptualizing the precarious. In E. Armano, A. Bove, \& A. Murgia (Eds.), Mapping precariousness, labour insecurity and uncertain livelihoods : subjectivities and resistance. (199-209). Florence: Routledge.

Martuccelli, Danilo (2007). Gramáticas del individuo. Buenos Aires: Losada.

Merton, Robert King (1936). The Unanticipated Consequences of Purposive Social Action. American Sociological Review, 1(6), 894904.

Ministerio de Empleo y Seguridad Social. (2014) Strategy for entrepreneurship and Youth Employment, Ministry of Employment and Social Security. Madrid: Spanish Government. Retrieved from: http://www.empleo.gob.es/ficheros/garantiajuvenil/documentos/E EEJ_Documento_en_INGLES.pdf [Consulted 16 June, 2018]

Morgan, George \& Nelligan, Pariece (2018). The Creativity Hoax: Precarious Work in the Gig Economy. London: Anthem Press.

Muñoz, David \& Santos, Antonio (2017). Las cárceles del capital humano: trabajo y vidas precarias en la juventud universitaria. Recerca, Revista De Pensament $i$ Análisi, 20(4), 59-78. http://dx.doi.org/10.6035/Recerca.2017.20.4

Neilson, Brett \& Rossiter, Ned (2008). Precarity as a political concept, or, fordism as exception. Theory, Culture \& Society, 25(7-8), 51-72.

OVJ, Observatorio Vasco de la Juventud (2018). Panorámica de la Juventud de Euskadi. Indicadores de Juventud 2017. Retrieved from: http://www.gazteaukera.euskadi.eus/r58-

$7651 x /$ es/contenidos/informacion/tableau_enplegua_18/es_def/ind ex.shtml [Consulted 16 June, 2018]

OECD, Organisation for Economic Co-operation and Development (2016). Skills for a Digital World. Paris: OECD Publishing. Retrieved from: https://www.oecd- 
ilibrary.org/content/paper/5jlwz83zzwnw-en. [Consulted 17 June, 2018]

Owen, Jan (2015). Foreword, The New Work Order: Ensuring young Australians have skills and experience for the jobs of the future, not the past. Melbourne: FYA.

Papadopoulos Dimitris, Stephenson, Niamh \& Tsianos, Vassilis (2008). Escape Routes: control and subversion in the twenty-first century. London: Pluto Press.

Parlamento Vasco (2012). LEY 16/2012, de 28 de junio, de Apoyo a las Personas Emprendedoras y a la Pequeña Empresa del País Vasco. Vitoria-Gasteiz: Parlamento Vasco. Retrieved from: https://www.euskadi.eus/yz2-

bopv/es/bopv2/datos/2012/o7/120306ga.shtml [Consulted 19 June, 2018]

Piketty, Thomas (2014). Capital in the Twenty-First Century. Cambridge, MA: Harvard University Press.

Rodríguez, Carlos \& Ramos, Javier (2016). El sistema español de Garantía Juvenil y Formación Profesional dual en el marco de la Estrategia de Empleo. Instituto Complutense de Estudios Internacionales, 1 (Working Papers), 1-39.

Rose, Nikolas \& Miller, Peter (1992). Political Power beyond the State: Problematics of Government. British Journal of Sociology, $43(2), 173-205$-SEPE:

Rose, Nikolas (1999). Governing the soul the shaping of the private self. London: Free Association Books.

Rose, Nikolas, \& Lentzos, Filippa (2017). Making Us Resilient: Responsible Citizens for Uncertain Times. In S. Trnka \& C. Trundle (Eds.), Competing Responsibilities: The Ethics and Politics of Contemporary Life (27-48). Durham: Duke University Press.

Sennett, Richard (2006). The Culture of the New Capitalism. New Haven \& London: Yale University Press. 
Santamaría, Elsa (2018). Jóvenes, crisis y precariedad laboral: una relación demasiado larga y estrecha. Encrucijadas, 15, 1-24.

Santos, Antonio (2014). La política en manos de los empresarios: el imparable ascenso de la ideología del emprendedor. Papeles de relaciones ecosociales y cambio global, 127, 29-43.

Serrano, Amparo \& Martín, Paz (2017) From 'Employab-ility' to 'Entrepreneurial-ity' in Spain: youth in the spotlight in times of crisis. Journal of Youth Studies, 20(7), 798-821.

Sloterdijk, Peter (2005/2013). In the World Interior of Capital. For a Philosophical Theory of Globalization. Cambrige: Polity Press.

Suárez, Borja (2017). Autoempleo (y emprendimiento) juvenil: ¿ahuyentar a los jóvenes de los derechos y garantías laborales? Cuadernos de Relaciones Laborales, 35(1), 151-164.

Thrift, Niguel (2005). Knowing Capitalims. London: SAGE.

Virno, Paolo (2001/2004). A Grammar of the Multitude. New York: Semiotext(e). 